\title{
Applications in the Nuclear Industry for Thermal Spray Amorphous Metal and Ceramic Coatings
}

\author{
J. BLINK, J. FARMER, J. CHOI, and C. SAW
}

Amorphous metal and ceramic thermal spray coatings have been developed with excellent corrosion resistance and neutron absorption. These coatings, with further development, could be cost-effective options to enhance the corrosion resistance of drip shields and waste packages, and limit nuclear criticality in canisters for the transportation, aging, and disposal of spent nuclear fuel. Iron-based amorphous metal formulations with chromium, molybdenum, and tungsten have shown the corrosion resistance believed to be necessary for such applications. Rare earth additions enable very low critical cooling rates to be achieved. The boron content of these materials and their stability at high neutron doses enable them to serve as high efficiency neutron absorbers for criticality control. Ceramic coatings may provide even greater corrosion resistance for waste package and drip shield applications, although the boron-containing amorphous metals are still favored for criticality control applications. These amorphous metal and ceramic materials have been produced as gas-atomized powders and applied as near full density, nonporous coatings with the high-velocity oxy-fuel process. This article summarizes the performance of these coatings as corrosion-resistant barriers and as neutron absorbers. This article also presents a simple cost model to quantify the economic benefits possible with these new materials.

DOI: $10.1007 / \mathrm{s} 11661-009-9830-4$

(C) The Author(s) 2009. This article is published with open access at Springerlink.com

\section{INTRODUCTION}

THE outstanding corrosion resistance that may be possible with structurally amorphous metals (SAMs) was recognized several years ago. ${ }^{[1-3]}$ Compositions of several iron-based amorphous metals were published, including some with very good corrosion resistance. Examples included thermally sprayed coatings of Fe-10Cr-10-Mo-(C,B), bulk Fe-Cr-Mo-C-B, and $\mathrm{Fe}-\mathrm{Cr}-\mathrm{Mo}-\mathrm{C}-\mathrm{B}-\mathrm{P}{ }^{[4-6]}$ The corrosion resistance of an iron-based amorphous alloy with yttrium (Y), $\mathrm{Fe}_{48} \mathrm{Mo}_{14} \mathrm{Cr}_{15} \mathrm{Y}_{2} \mathrm{C}_{15} \mathrm{~B}_{6}$ was also established. ${ }^{[7-9]}$ Yttrium was added to this alloy to lower the critical cooling rate. Because nickel-based crystalline materials have excellent corrosion resistance, several nickel-based amorphous metals have also been developed by other researchers and were compared with thermal spray coatings of crystalline materials. Nickel-based amorphous materials exhibited exceptional corrosion performance in acids, and thermal spray coatings of crystalline nickel-based alloy appear to have less corrosion resistance than

J. BLINK, J. FARMER, and C. SAW, Doctors, are with the Lawrence Livermore National Laboratory, Livermore, CA 94550. Contact e-mail: blink1@1lnl.gov J. CHOI, formerly with the Lawrence Livermore National Laboratory, Livermore, CA, is Doctor with Tokyo University, Tokyo, Japan.

This article is based on a presentation given in the symposium entitled "Iron-Based Amorphous Metals: An Important Family of High-Performance Corrosion-Resistant Materials," which occurred during the MSandT meeting, September 16-20, 2007, in Detroit, Michigan, under the auspices of The American Ceramics Society (ACerS), The Association for Iron and Steel Technology (AIST), ASM International, and TMS.

Article published online April 10, 2009 comparable nickel-based amorphous metals. ${ }^{[10]}$ The study reported here focuses on iron-based amorphous metals that have the potential to rival the corrosion resistance of nickel-based crystalline or amorphous materials at significantly lower cost.

A family of iron-based amorphous metals with very good corrosion resistance has been developed that can be applied as a protective thermal spray coating. One of the most promising formulations within this family was found to be $\mathrm{Fe}_{49.7} \mathrm{Cr}_{17.7} \mathrm{Mn}_{1.9} \mathrm{Mo}_{7.4} \mathrm{~W}_{1.6} \mathrm{~B}_{15.2} \mathrm{C}_{3.8} \mathrm{Si}_{2.4}$ (SAM2X5), which included chromium (Cr), molybdenum (Mo), and tungsten (W), for enhanced corrosion resistance, and boron (B) to enable glass formation and neutron absorption. ${ }^{[1-15]}$ The parent alloy for this series of amorphous alloys, which is known as SAM40 and represented by the formula $\mathrm{Fe}_{52.3} \mathrm{Cr}_{19} \mathrm{Mn}_{2} \mathrm{Mo}_{2.5} \mathrm{~W}_{1.7}$ $\mathrm{B}_{16} \mathrm{C}_{4} \mathrm{Si}_{2.5}$, has less molybdenum than SAM2X5 and was originally developed by Branagan. ${ }^{[16,17]}$ Another similar and promising iron-based SAM material is SAM1651, $\mathrm{Fe}_{48} \mathrm{Mo}_{14} \mathrm{Cr}_{15} \mathrm{Y}_{2} \mathrm{C}_{15} \mathrm{~B}_{6}$.

\section{POSSIBLE APPLICATIONS}

The SAM material SAM2X5 may have beneficial application as a neutron absorber, supporting the safe long-term disposal of spent nuclear fuel (Figures 1 and 2). This material has exceptional neutron absorption characteristics and is stable at high dose. The absorption cross section in transmission for thermal neutrons for SAM2X5 coatings is 3 to 4 times greater than that of borated stainless steel and twice as good as nickel-based alloy C-4 
with additions of $\mathrm{Gd}(\mathrm{Ni}-\mathrm{Cr}-\mathrm{Mo}-\mathrm{Gd}) .^{[18-20]}$ It may be possible to achieve substantial cost savings by substituting these new Fe-based materials for more expensive Ni-Cr-Mo and Ni-Cr-Mo-Gd alloys. Thermal spray coatings of Fe-based amorphous metals are predicted to cost $\sim \$ 7$ per pound, whereas plates of Ni-Cr-Mo are expected to cost $\geq \$ 37$ per pound, based upon actual purchase costs of alloy C-22, without additions of gadolinium.

The SAM material SAM1651 is another material that could be used as a corrosion-resistant coating on waste packages or drip shields in a repository. This material is already being used in a similar role as corrosionresistance deck coatings for some naval vessels.

The hardness values for type 316L stainless steel, nickel-based alloy C-22, and HVOF SAM2X5 are 150, 250, and 1100 to $1300 \mathrm{VHN}$, respectively. The SAM material is extremely hard and provides enhanced resistance to abrasion and gouges. In fact, successful tests have been conducted for applications as disk cutters for the tunnel boring machines (Figure 3).

\section{THERMAL SPRAY COATINGS}

The coatings discussed here were made with the highvelocity oxy-fuel (HVOF) process (Figure 4), which involves a combustion flame and is characterized by gas and particle velocities that are 3 to 4 times the speed of sound (mach 3 to 4 ). This process is ideal for depositing metal and cermet coatings, which have typical bond strengths of 5000 to 10,000 pounds per square inch ( 5 to $10 \mathrm{ksi}$ ), porosities of $<1$ pct, and extreme hardness. The cooling rate that can be achieved in a typical thermal spray process such as HVOF is on the order of $10^{4} \mathrm{~K} / \mathrm{s}$, and is high enough to enable many alloy compositions to be deposited above their respective critical cooling rate, thereby maintaining the vitreous state. However, the range of amorphous metal compositions that can be processed with HVOF is more restricted than those that can be produced with melt spinning, due to the differences in achievable cooling rates. Both kerosene and hydrogen have been investigated as fuels in the HVOF process used to deposit SAM2X5 and SAM1651. Type $316 \mathrm{~L}$ stainless-steel cylinders were coated with SAM2X5 and served as half-scale models of waste packages for the storage of spent nuclear fuel. SAM2X5-coated cylinders and plates were subjected to eight full cycles in the General Motors (GM) salt fog test. The results of salt-fog testing are discussed in a subsequent section of this article. Cylinders have also been coated with the Y-containing SAM1651 and tested.

\section{CORROSION PERFORMANCE}

\section{A. Samples Used for Immersion and Salt Fog Testing}

A wide variety of standardized coating samples were made for corrosion testing, as shown in Figure 5.

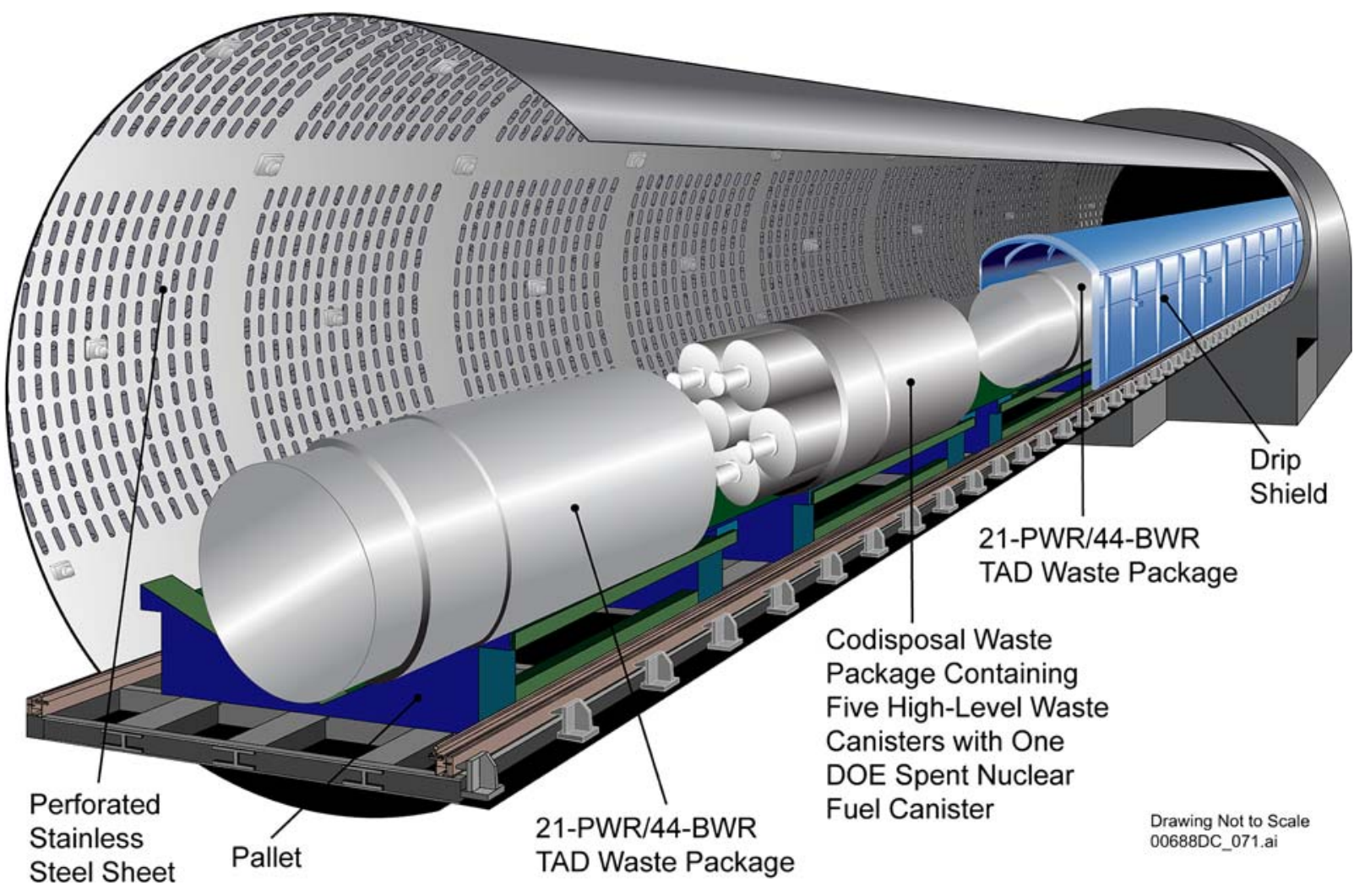

Fig. 1-Three-dimensional illustration of waste packages for spent nuclear fuel and high-level radioactive wastes in a typical drift (tunnel) at the Yucca Mountain site. Waste packages are protected from dripping water and falling rocks by the drip shield. A SAM coating on the exterior of the waste packages or drip shields could improve repository performance. 


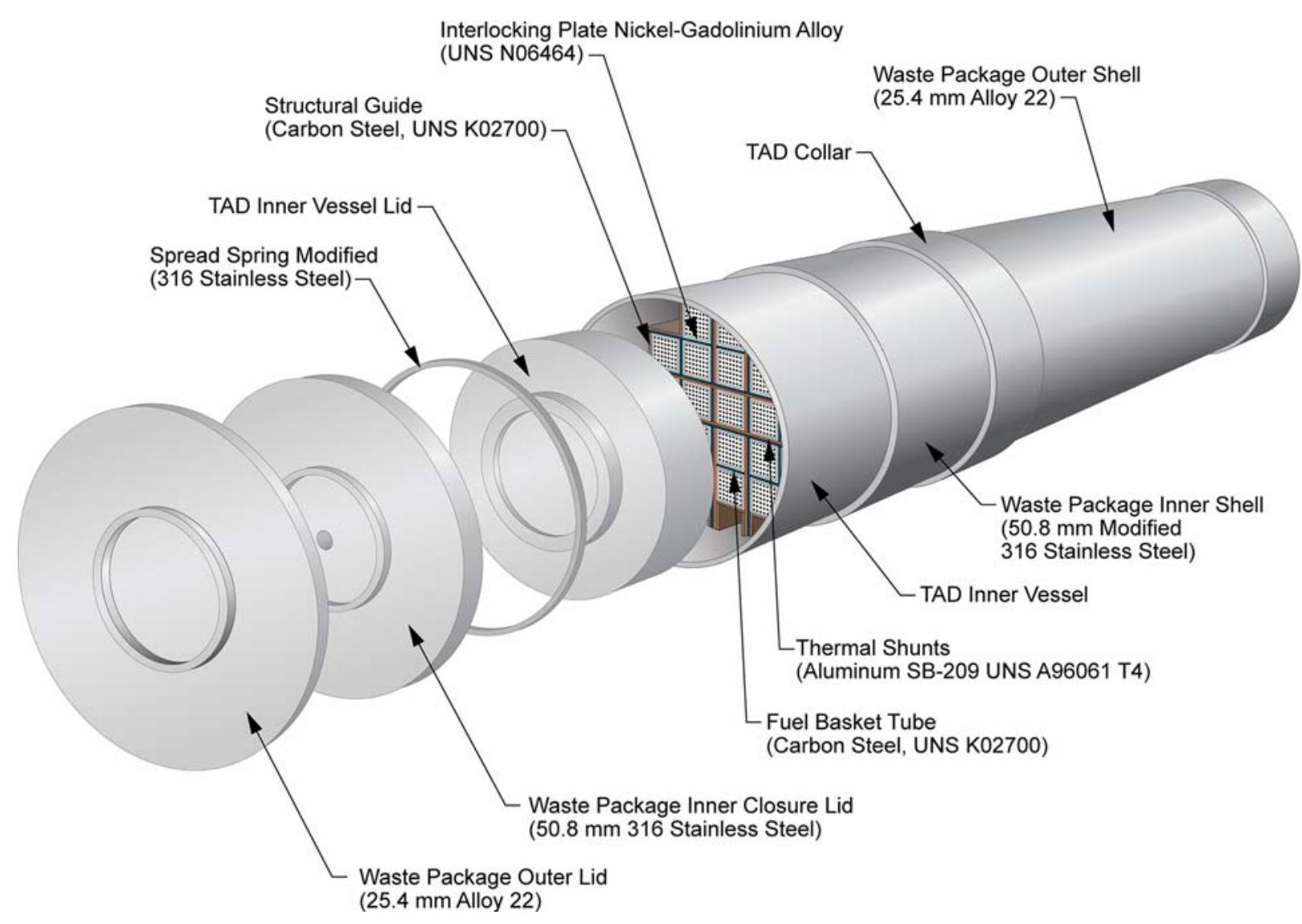

Fig. 2-More detailed representation of a spent nuclear fuel waste package, sized to accommodate 21-PWR fuel assemblies. The fuel basket tubes include neutron absorbers. In addition to a potential use of a SAM material as an exterior coating for corrosion resistance, a SAM material is also an option for criticality control (replacing the nickel-gadolinium alloy or borated stainless steel shown).

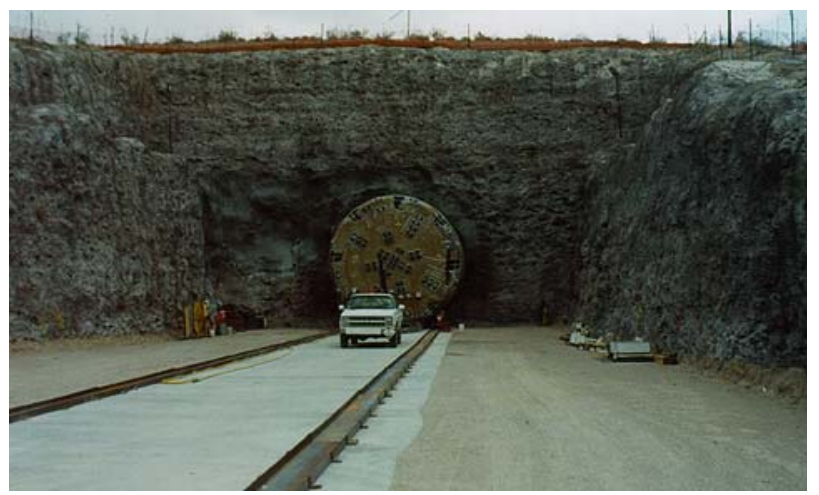

Fig. 3-Face of tunnel boring machine exiting Yucca Mountain after construction of the initial tunnel, which is known as the Exploratory Studies Facility. The SAM materials are an option for the disk cutters for tunnel boring machines that will be required to excavate the $65 \mathrm{~km}$ of 5 -m-diameter emplacement drifts at Yucca Mountain.

Samples of the powders used are in the bottles at the top. Crevice samples with a bolt hole in the center are shown on the left. Alloy C-22 rods coated with SAM2X5 and SAM1651, used to monitor open-circuit corrosion potentials and corrosion rates, as determined with linear polarization, are shown on the right. Weight loss samples used for long-term immersion testing are shown in the front center. Ultrathick $(\sim 0.75 \mathrm{~cm})$ coatings are also shown, slightly to the right of center.

\section{B. Verification of Amorphous Nature of Powder and Coatings}

$\mathrm{X}$-ray diffraction (XRD) measurements were made of SAM2X5 thermal spray coatings deposited on both alloy C-22 and type 316L stainless steel substrates. Figure 6 shows examples from powders with different ranges of particle sizes. The broad halo observed at $2 \theta \sim 44 \mathrm{deg}$ indicates that the coating was predominately amorphous, and the small sharp peaks are attributed to the presence of minor crystalline phases. ${ }^{[21,22]}$ These phases are believed to include $\mathrm{Cr}_{2} \mathrm{~B}, \mathrm{WC}, \mathrm{M}_{23} \mathrm{C}_{6}$, and bcc ferrite, which are known to have a detrimental effect on corrosion performance. The deleterious precipitates deplete the amorphous matrix of alloying elements such as chromium that are responsible for enhanced passivity. Figure 6 also shows a coating (lower right) with almost no residual crystalline phase. The very slight residual crystalline peaks to the left of the halo for this coating are attributed to a small amount of $\mathrm{M}_{23} \mathrm{C}_{6}$ and $\mathrm{WC}$ formed during thermal spraying. Even this level of residual crystalline structure was eliminated in later thermal spray coatings with optimized SAM1651 formulations. 

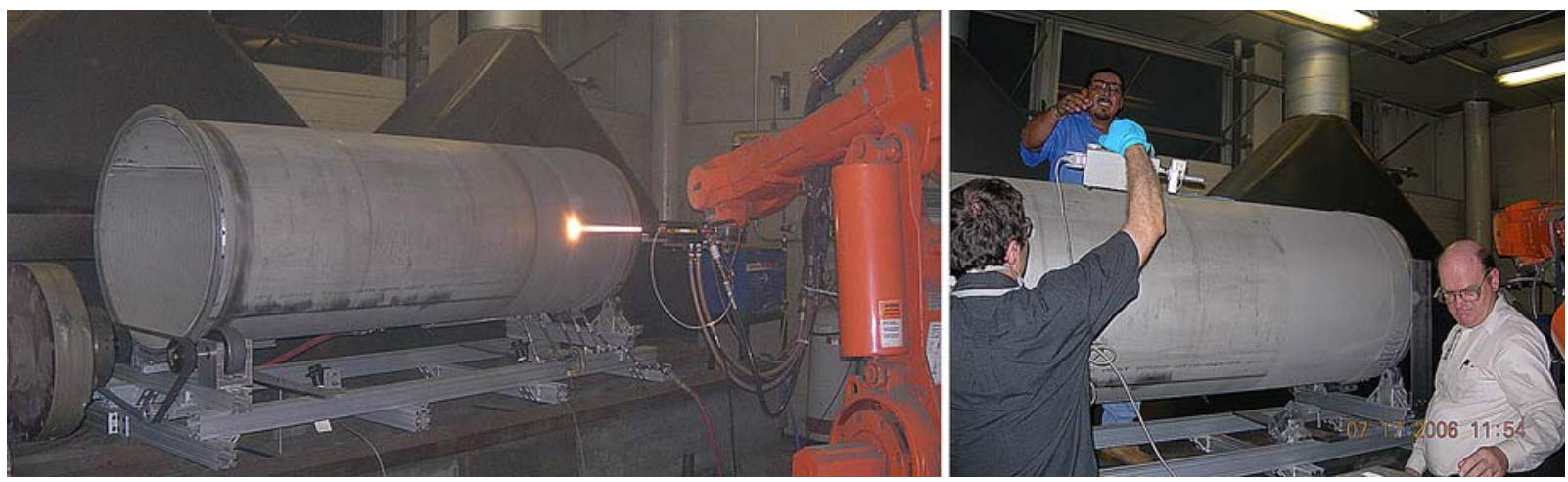

Fig. 4-High-velocity oxy-fuel process at Caterpillar used to coat half-scale waste packages with SAM1651 amorphous metal. The torch is shown in the left frame, and the quality assurance checks of the coating thickness and roughness are shown in the right frame.

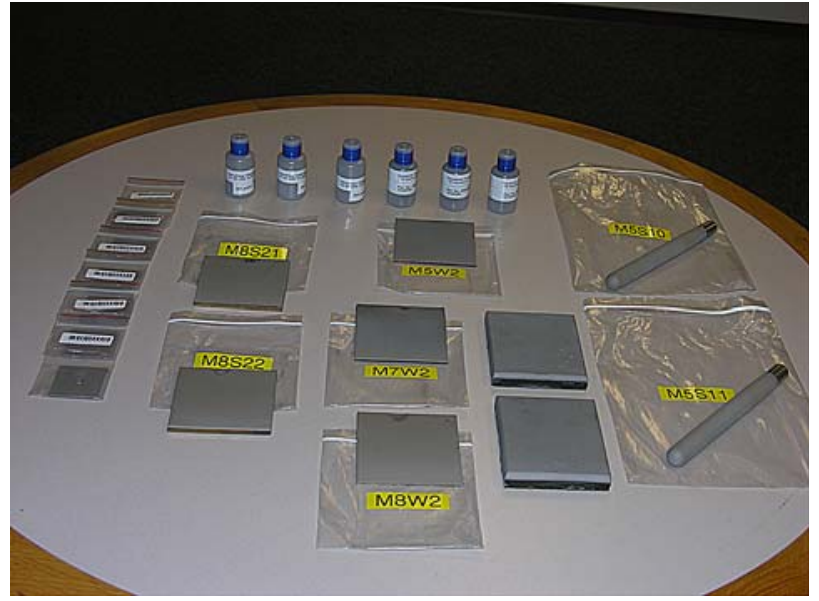

Fig. 5-Samples of amorphous-metal HVOF coatings used for longterm corrosion testing.

\section{Solutions Used for Long-Term Immersion Tests}

Ground water in the proposed repository at Yucca Mountain has been classified in three general categories, depending upon the terminal compositions that evolve during evaporative concentration. These categories include calcium chloride, sulfate-chloride, and bicarbonate. In general, the calcium chloride brines are the most aggressive, and the bicarbonate brines are the least aggressive. Samples taken from exploratory wells at Yucca Mountain fall into all three water-type categories, as shown in Figure 7. Standardized test solutions therefore have been developed, which also fall into each ground water category. These synthetic brines were based upon concentrated J-13 well water, and are known as simulated dilute water (SDW), simulated concentrated water $(\mathrm{SCW})$, and simulated acidic water $(\mathrm{SAW}){ }^{[23-27]}$

\section{Results of Long-Term Immersion Tests}

Initially, linear polarization was used to determine the corrosion rates of SAM2X5 coatings and wrought alloy C-22 in several environments, including natural seawater and $5 \mathrm{M} \mathrm{CaCl}_{2}$ at $105^{\circ} \mathrm{C}$, after an immersion of a few days. Table I shows that the rates determined for alloy C-22 and SAM2X5 are comparable under these conditions.

Long-term weight-loss data for SAM2X 5 were also needed. After 135 days immersion, weight loss was used to determine the corrosion rates of SAM2X5 coatings on alloy C-22 weight-loss samples (Figure 8). Depending upon the assumed coating density, these rates were determined to be (1) 14.3 to $15.9 \mu \mathrm{m} /$ year in natural seawater at $90{ }^{\circ} \mathrm{C}$; (2) 8.4 to $9.3 \mu \mathrm{m} /$ year in 3.5 -molal $\mathrm{NaCl}$ solution at $30{ }^{\circ} \mathrm{C}$; (3) 26.1 to $29.7 \mu \mathrm{m} /$ year in 3.5 molal $\mathrm{NaCl}$ solution at $90{ }^{\circ} \mathrm{C}$; (4) 4.6 to $5.1 \mu \mathrm{m} /$ year in 3.5-molal $\mathrm{NaCl}$, and 0.525 -molal $\mathrm{KNO}_{3}$ solution at $90{ }^{\circ} \mathrm{C}$; (5) 8.3 to $9.4 \mu \mathrm{m} /$ year in SDW at $90{ }^{\circ} \mathrm{C}$; (6) 2.8 to $3.0 \mu \mathrm{m} /$ year in $\mathrm{SCW}$ at $90{ }^{\circ} \mathrm{C}$; and (7) 16.5 to 18.1 $\mu \mathrm{m} /$ year in SAW at $90{ }^{\circ} \mathrm{C}$. As expected, greater corrosion rates were observed at higher temperature (compare results (2) and (3)), and nitrate anion inhibited the corrosion of these iron-based materials in concentrated chloride solutions (compare results (3) and (4)). Corrosion rates in bicarbonate-type brines were less than those in concentrated chloride solutions (compare results (5) and (6) with result (3)).

\section{SALT FOG PERFORMANCE}

Salt fog tests were conducted according to the standard GM salt fog test, identified as GM9540P. ${ }^{[11]}$ Early Fe-based amorphous metal coatings had very poor corrosion resistance and failed salt-fog tests. To determine if the newer SAMs have better performance, thermal-spray coatings of SAM2X5 and SAM1651 coatings were tested, with 1018 steel serving as control samples. After eight cycles in this salt-fog test, SAM2X5 and SAM1651 coatings on flat plates and a half-scale spent nuclear fuel (SNF) prototypical waste package proved to be corrosion resistant, whereas the steel reference samples underwent aggressive attack (Figures 9 and 10). In the case of the SAM1651-coated waste package, some running rust was observed on the bottom of the waste package, which may be due to surface preparation prior to coating (Figure 10). 

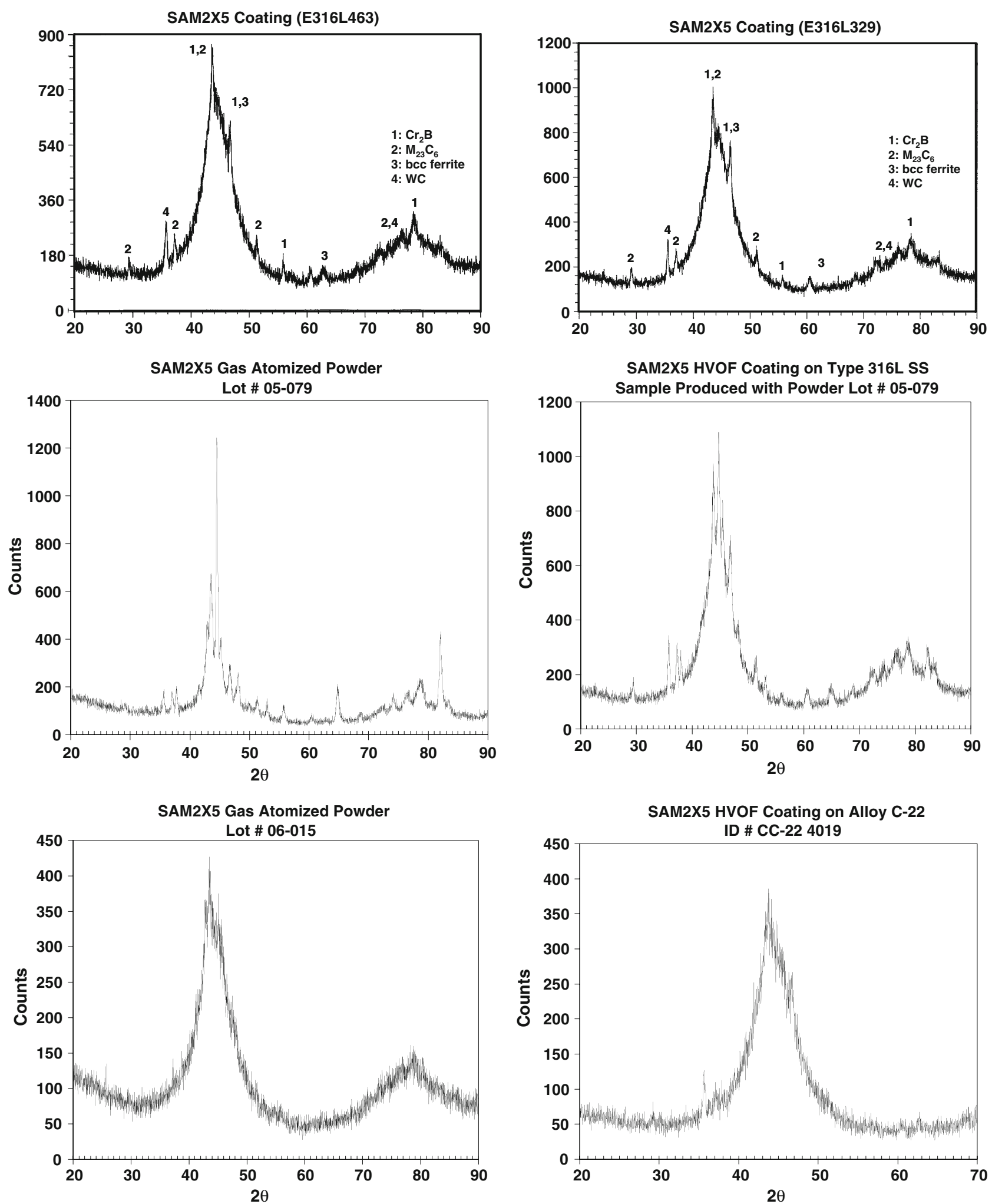

Fig. 6-X-ray diffraction data for amorphous SAM2X5 powder. The top left data are from lot 04-265 powder, which had a broad range of particle sizes $(-53 /+15 \mu \mathrm{m})$, and the top right data are from lot $04-200$, which had a more coarse range of particle sizes $(-53 /+30 \mu \mathrm{m})$. Both samples show the presence of $\mathrm{Cr}_{2} \mathrm{~B}$, WC, $\mathrm{M}_{23} \mathrm{C}_{6}$, and bcc ferrite. The middle row of data shows partly devitrified powder on the left and the resulting imperfect amorphous metal coating on the right. A meticulous and painstaking process control was used to eliminate the deleterious (to corrosion resistance) crystalline phases. The bottom row of data shows a virtually completely amorphous powder on the left, resulting in the virtually completely amorphous coating on the right. 


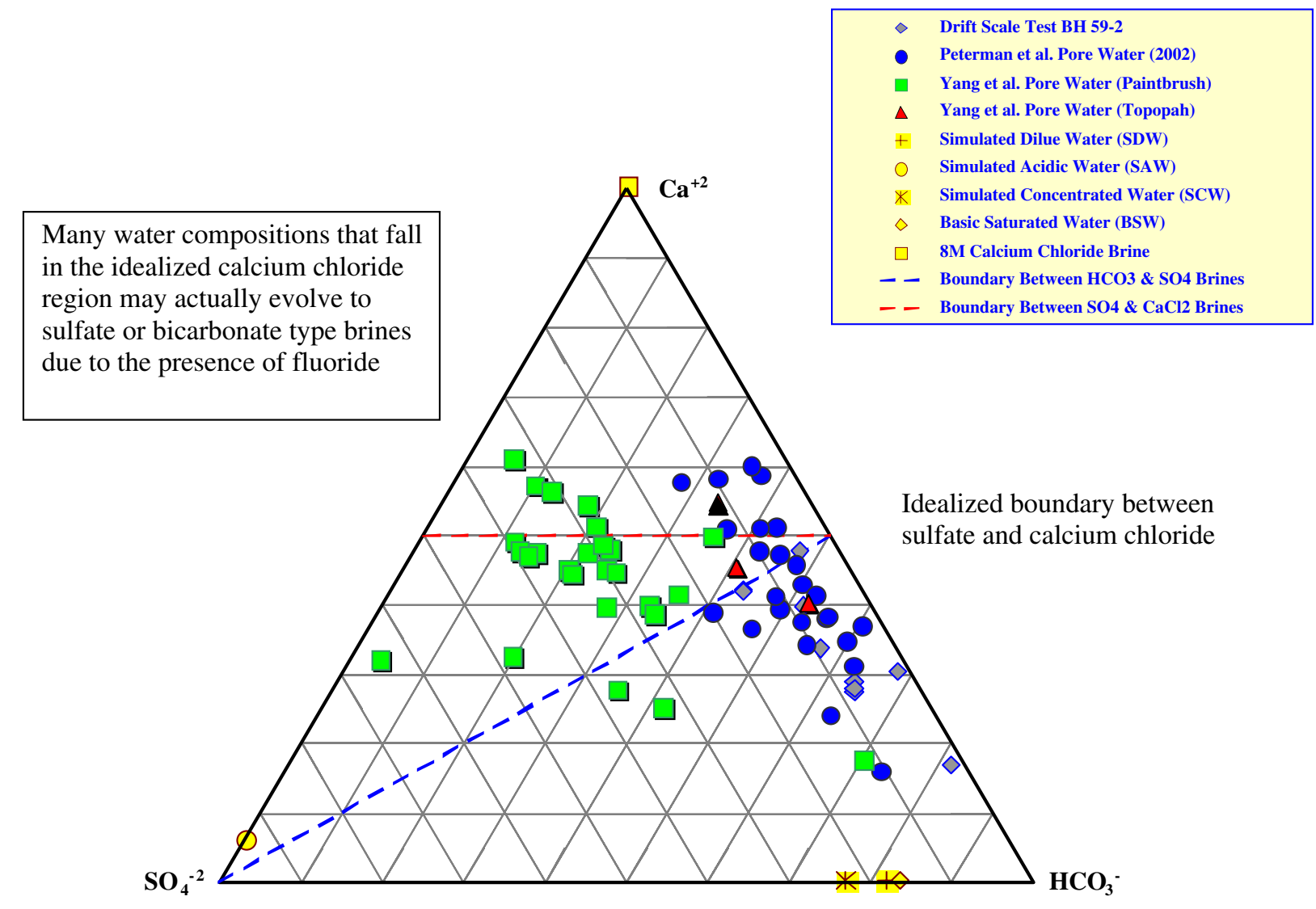

Fig. 7- Ground water in the proposed underground repository at Yucca Mountain has been classified as calcium chloride brine, sulfate-chloride brine, or bicarbonate brine.

Table I. Corrosion Rates of Alloy C-22 and SAM2X5 HVOF Coatings in Seawater

\begin{tabular}{|c|c|c|c|}
\hline Environment & Sample & $E_{\text {corr }}(\mathrm{mV} v s \mathrm{SSC})$ & Corrosion Rate ( $\mu \mathrm{m} /$ year) \\
\hline $30^{\circ} \mathrm{C}$ seawater & HVOF SAM2X5 & -87.4 & 0.18 \\
\hline $30{ }^{\circ} \mathrm{C}$ seawater & wrought alloy C-22 & -163.2 & 0.09 \\
\hline $90^{\circ} \mathrm{C}$ seawater & HVOF SAM2X5 & -241.0 & 1.58 \\
\hline $90^{\circ} \mathrm{C}$ seawater & wrought alloy C-22 & -318.2 & 1.22 \\
\hline $105^{\circ} \mathrm{C} 5 \mathrm{M} \mathrm{CaCl}_{2}$ & HVOF SAM $2 \times 5$ & -240.9 & 2.70 \\
\hline $105{ }^{\circ} \mathrm{C} 5 \mathrm{M} \mathrm{CaCl}_{2}$ & wrought alloy C-22 & -464.3 & 5.04 \\
\hline $105^{\circ} \mathrm{C} 5 \mathrm{M} \mathrm{CaCl}_{2}$ & HVOF Alloy C-22 & -347.9 & 115.70 \\
\hline
\end{tabular}

Note: SSC is silver:silver chloride.

\section{NEUTRON ABSORPTION}

The high boron content of $\mathrm{Fe}_{49.7} \mathrm{Cr}_{17.7} \mathrm{Mn}_{1.9}$ $\mathrm{Mo}_{7.4} \mathrm{~W}_{1.6} \mathrm{~B}_{15.2} \mathrm{C}_{3.8} \mathrm{Si}_{2.4}$ (SAM2X5) makes it an effective neutron absorber and suitable for criticality control applications. As shown in Figure 11, average measured values of the neutron absorption cross section in transmission $\left(\Sigma_{t}\right)$ for type $316 \mathrm{~L}$ stainless steel, alloy C-22, borated stainless steel, a Ni-Cr-MoGd alloy, and SAM2X5 have been determined to be approximately $1.1,1.3,2.3,3.8$, and $7.1 \mathrm{~cm}^{-1}$, respectively. ${ }^{[19,20]}$ SAM2X5 and its parent alloy have been shown to maintain corrosion resistance up to the glass transition temperature and to remain in the amorphous state after receiving a relatively high neutron dose.

Simulations and design calculations at LLNL show that $k$ effective $\left(k_{\text {eff }}\right)$ can be lowered by at least $10 \mathrm{pct}$ with the application of a 1-mm-thick coating of SAM2X5 to the SNF support structure (basket) in a prototypical waste package (Figures 1,2, and 12). Even better performance is possible through the use of enriched boron for the synthesis of the Fe-based amorphous metal. The Fe-based amorphous metals have already been produced in multiton quantities and 


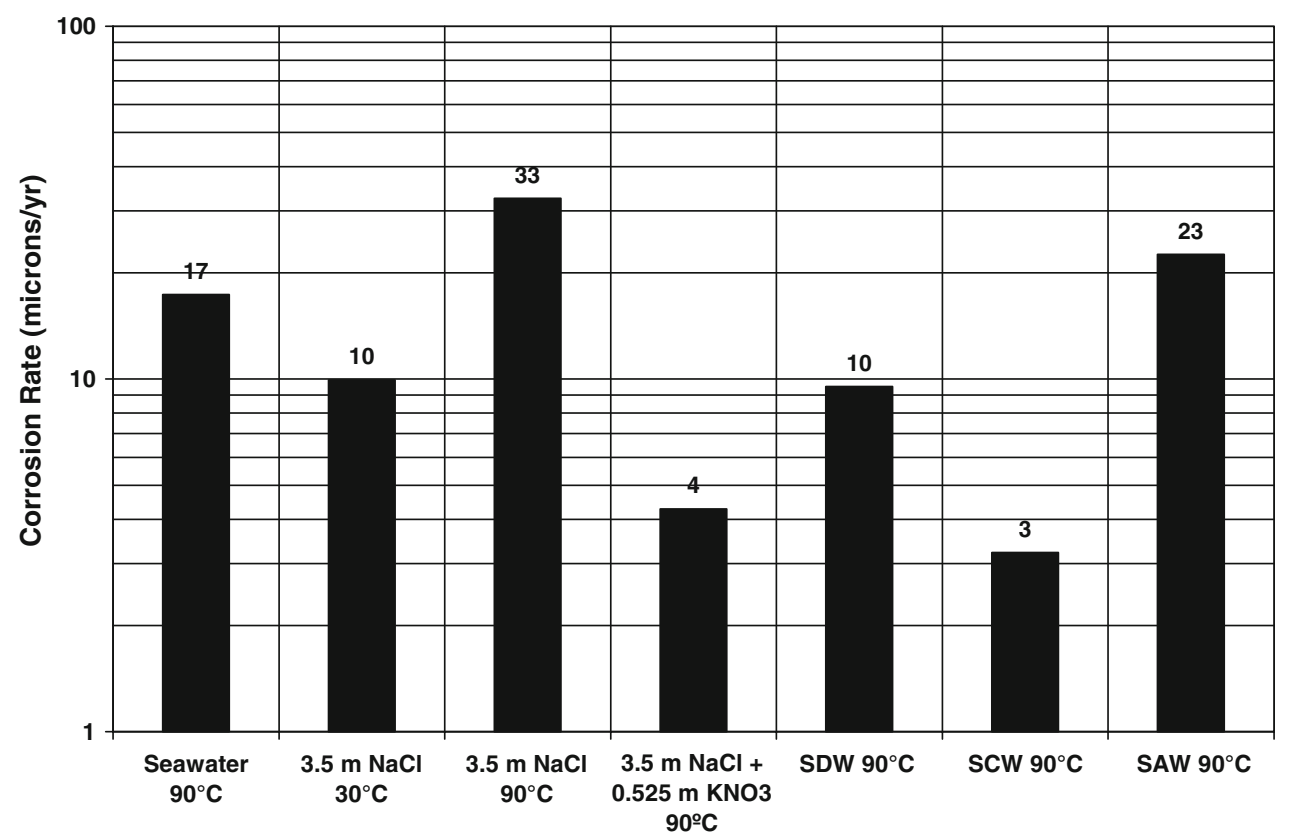

Fig. 8 - Corrosion rates of amorphous SAM2X5 coatings, based upon weight loss measured after 135-day immersion test.
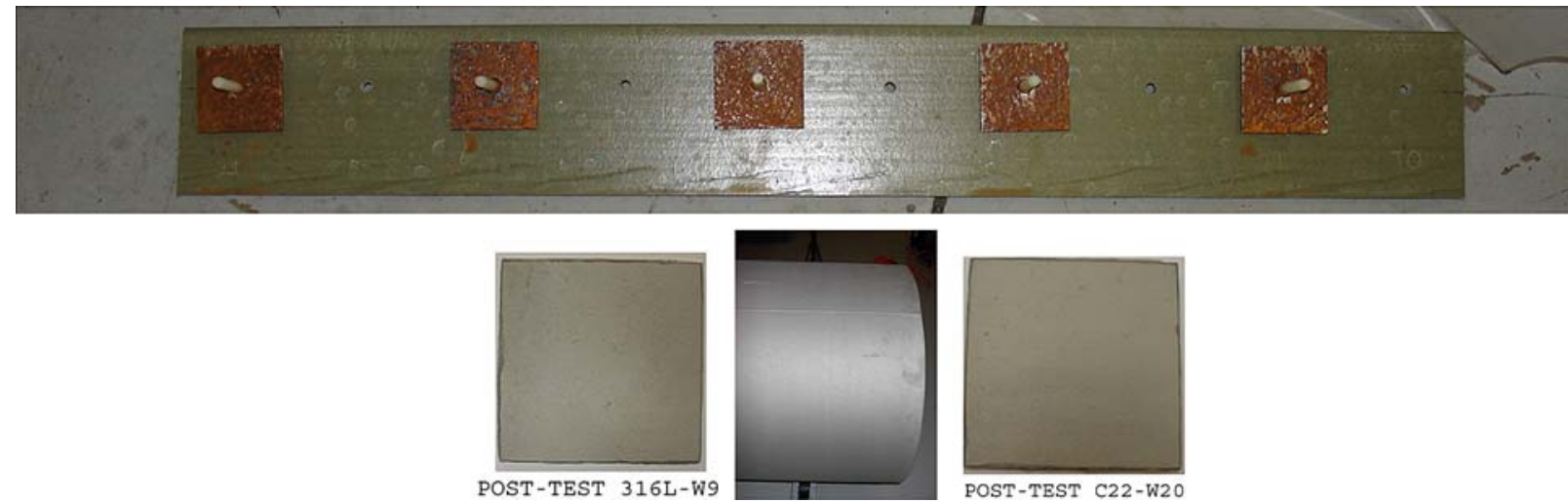

Fig. 9-Effect of GM9540P salt-fog test on 1018 steel reference samples (top), HVOF coating of SAM1651 amorphous metal on 316L and C-22 substrates (bottom right and left), and half-scale SNF prototypical waste package (bottom center).
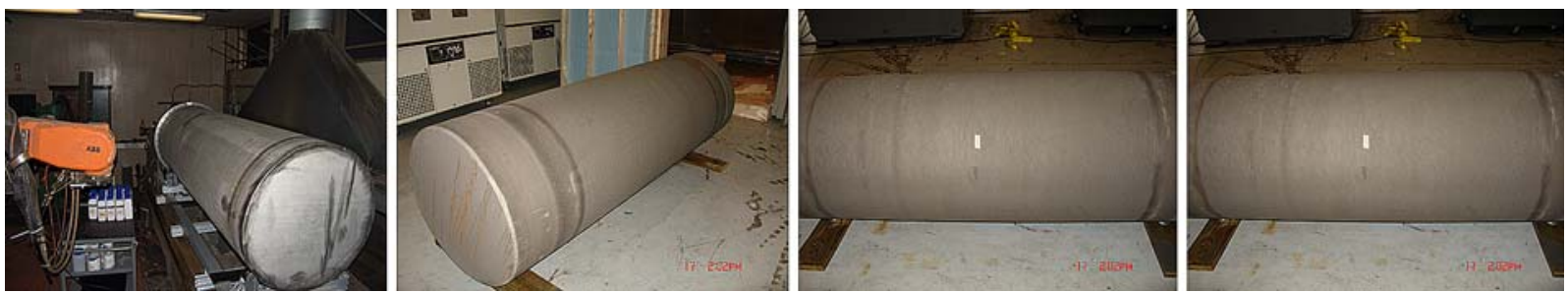

Fig. 10-Effect of GM9540P salt-fog test on HVOF coating of SAM1651 amorphous metal on a half-scale SNF prototypical waste package.

should cost less than $\$ 10$ per pound (Figure 14), while relatively few (three or four) 300-pound heats have been made of the Ni-Gd material, which may cost nearly $\$ 40$ per pound.

\section{ECONOMIC BENEFITS}

A cost model was developed and used to predict the cost to produce nickel-based alloys, including type 316 


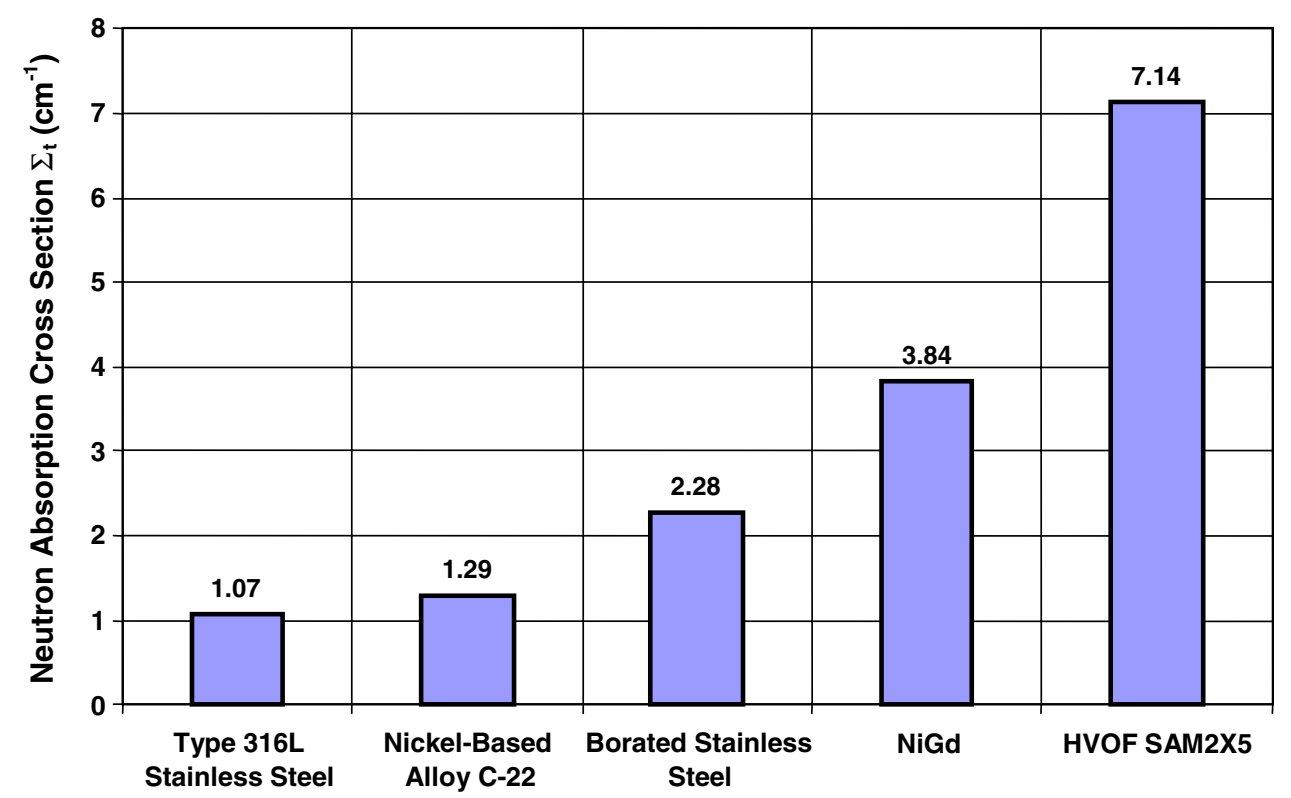

Fig. 11-Average measured values of the neutron absorption cross section in transmission $\left(\Sigma_{t}\right)$ for type $316 \mathrm{~L}$ stainless steel, alloy C-22, borated stainless steel, a Ni-Cr-Mo-Gd alloy, and SAM2X5.
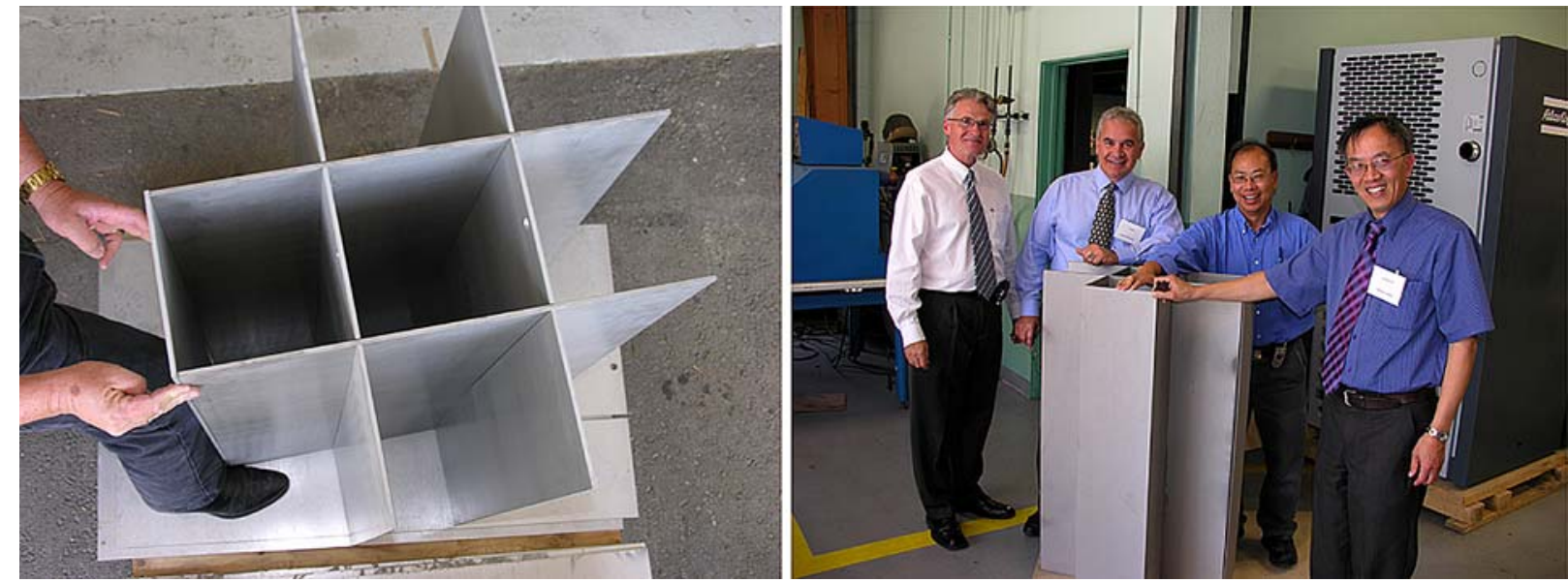

Fig. 12-Prototypical half-scale half-length basket assembly, sized to fit inside the half-scale waste packages. Shown after fabrication by water-jet cutting (left) and after coating with SAM2X5 (right).

stainless steel as well as nickel-based alloys C-276 and C-22. This cost model used raw materials data compiled by the United States Geological Survey (USGS) and represented graphically in Figure 13.

The cost model made the following assumptions:

1. throughput $=1$ waste package, 1 pallet, 1 drip shield per day;

2. floor space $=75,000$ square feet at $\$ 500$ per square foot;

3. personnel $=15 \mathrm{FTE}$ at $\$ 250,000$ per person per year;

4. equipment $=39 \mathrm{HVOF}$ guns $(30 \mathrm{lb} / \mathrm{h})$ at $\$ 250,000$ per gun; and

5. feed cost $=\$ 3 / 1 \mathrm{~b}$ (possible), $\$ 6 / \mathrm{lb}$ (midrange), $\$ 8 / \mathrm{lb}$ (bounding)
Based upon this model, the estimated raw material costs in 2004 for nickel-based alloys C-276 and C-22 were $\$ 22$ to $23 / \mathrm{lb}$. The most recent procurements of alloy C-22 by these authors was at a cost of $\$ 37 / \mathrm{lb}$, indicating that the model is probably underestimating costs due to the time lag in the data on the USGS web site. More exotic nickel-based alloys proposed for use as criticality control materials, such at Ni-Cr-Mo-Gd, will cost even more due to the incorporation of gadolinium as a neutron poison. The cost of type 316L stainless steel is estimated to be approximately $\$ 7 / \mathrm{lb}$. HVOF coatings of SAM2X5 and SAM1651 are predicted to cost $\$ 10$ to $\$ 15$ per pound, respectively, including the cost of the substrate (Figure 14).

Assuming acceptable materials performance, the following potential cost savings are estimated for an 


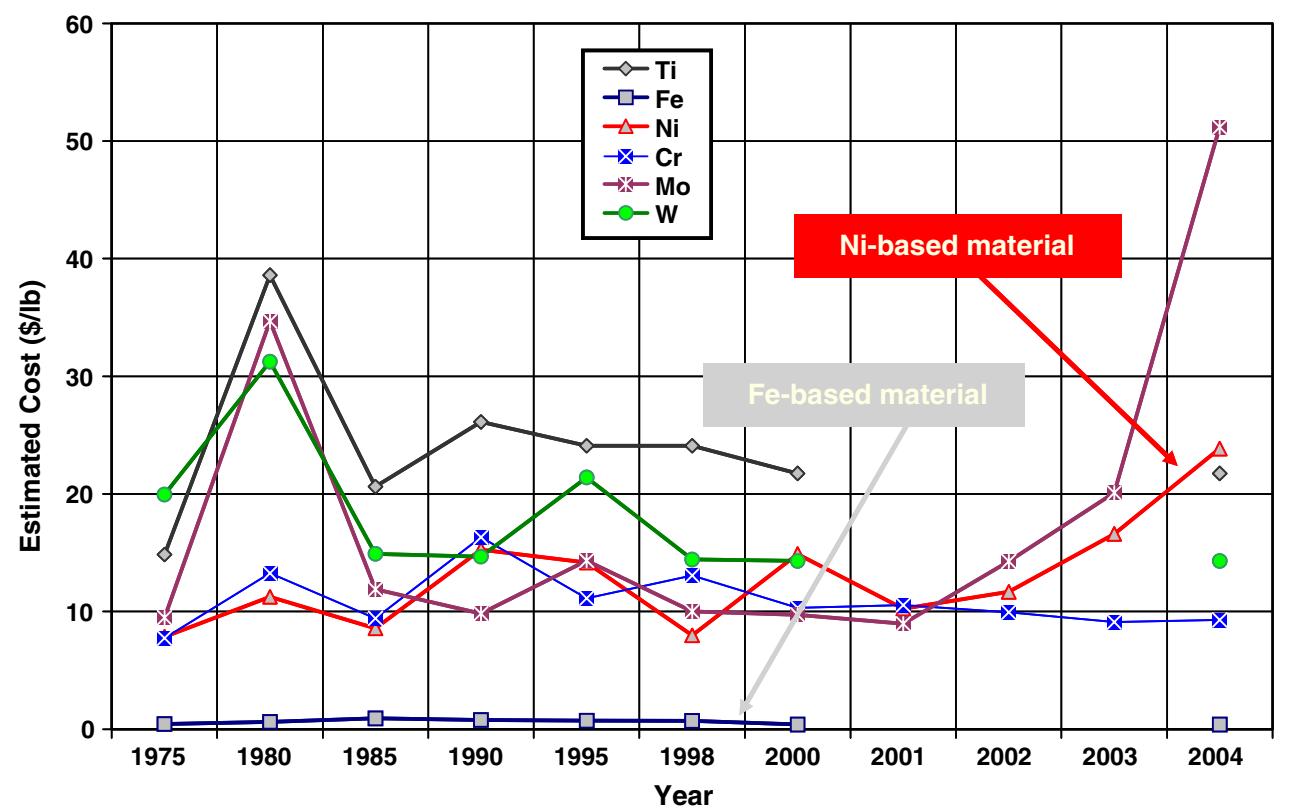

Fig. 13 - Cost of raw materials required for the production of type 316L stainless steel, alloy C-22, Fe-based amorphous metals, and titanium alloys. These costs were taken from the USGS web site, where raw materials are tracked ${ }^{[28]}$.

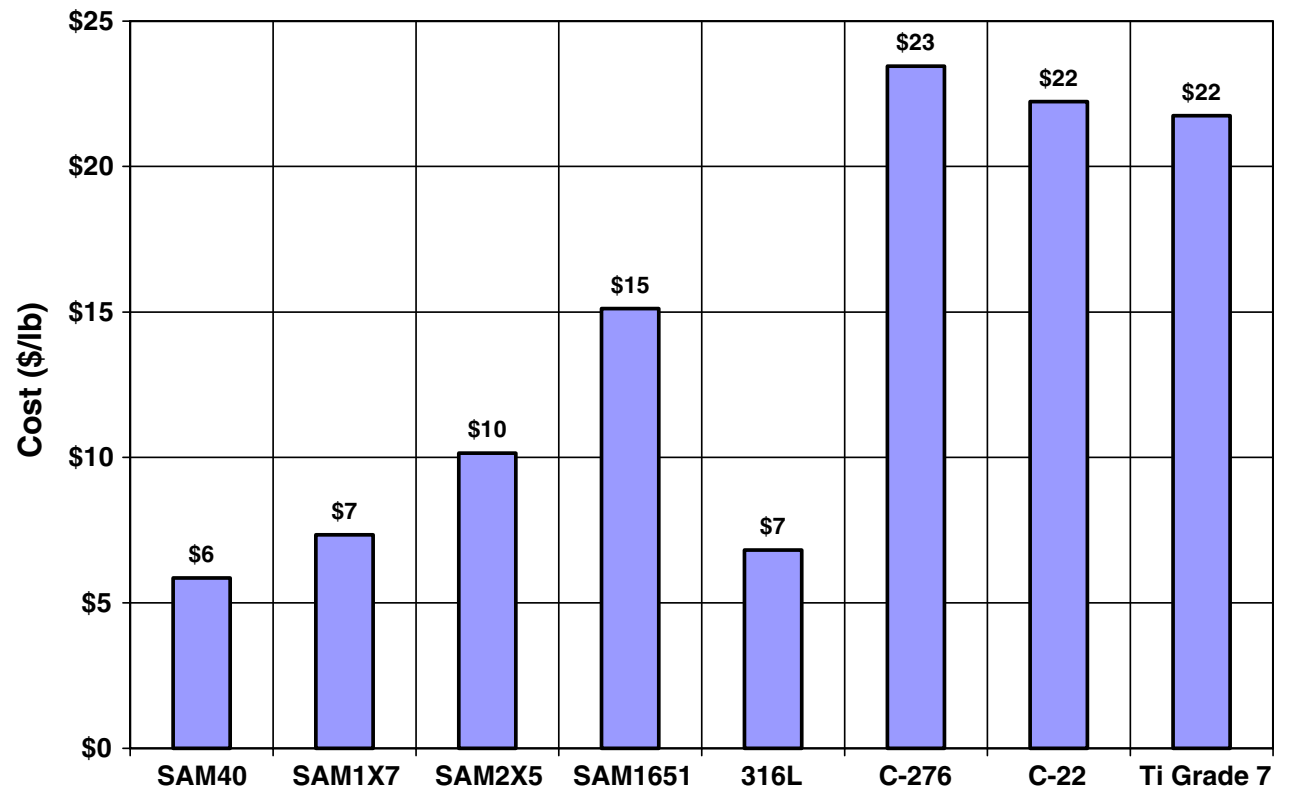

Fig. 14 -Estimates of finished materials costs, based upon the cost model, assumptions, and raw materials costs.

iron-based material that, with further development, could be substituted for the more expensive nickelbased materials now specified for fabrication of waste packages and emplacement pallets, and for titanium alloys now specified for fabrication of drip shields.

1. For $\$ 3 / 1 b$ feed cost: Substantial potential savings are estimated for the $\sim 11,000$ waste packages (42 pct, \$881 M), pallets (24 pct, \$41 M), and drip shields (81 pct, \$2.8B).

2. For $\$ 6 / 1 \mathrm{~b}$ feed cost: Reasonable potential savings (7 pct, \$271 M) are estimated for the waste package, no savings for the pallet, and large savings for the drip shield (70 pct, \$2.5B).

3. For $\$ 8 / 1 \mathrm{~b}$ feed cost: No savings are estimated for the waste package or pallet, but substantial potential savings are estimated for the drip shield (63 pct, \$2.3B).

\section{CONCLUSIONS}

Lawrence Livermore National Laboratory and its partner organizations have developed new Fe-based 
amorphous-metal alloys with good corrosion resistance, high hardness, and exceptional absorption cross sections for thermal neutrons. References 29 through 43 are additional references that describe development work for these alloys. More than 40 high-performance Fe-based amorphous alloys were systematically designed and synthesized. The $\mathrm{Cr}$, Mo, and W were added to enhance corrosion resistance; $\mathrm{Y}$ was added to lower the critical cooling rate; and $\mathrm{B}$ was added to render the alloy amorphous and to enhance the capture of thermal neutrons. Enriched boron could be used for the further enhancement of the absorption of thermal neutrons. Although not discussed in this article, phase stability has been demonstrated well above $500{ }^{\circ} \mathrm{C}$ to $600^{\circ} \mathrm{C}$ and at high neutron dose (equivalent to 4000 years inside the YM waste package). With additional development, these materials could be considered for use to achieve possible cost benefits for the fabrication of next-generation spent nuclear fuel waste packages, emplacement pallets, and drip shields, and for basket assemblies with enhanced criticality safety. Multiton quantities of gas-atomized SAM2X5 and SAM1651 powder have been produced and applied as protective coatings on numerous prototypes and parts. These new materials have several potential large-scale applications of national importance, including (1) corrosion-resistant antiskid decking for ships, and (2) several potential uses in a nuclear repository, including criticality control material, corrosion resistant coatings, and tunnel boring machine cutter disks.

\section{ACKNOWLEDGMENTS}

This work was performed by Lawrence Livermore National Laboratory under Contract No. W-7405-Eng48 and under the auspices of the United States Department of Energy. This work was cosponsored by the Office of Civilian and Radioactive Waste Management (OCRWM) of the United States Department of Energy (DOE) and the Defense Science Office (DSO) of the Defense Advanced Research Projects Agency (DARPA). The guidance of Jeffrey Walker, DOE OCRWM, and Leo Christodoulou, DARPA DSO, is gratefully acknowledged. The production of gasatomized powders by The NanoSteel Company and Carpenter Powder Products and the production of coatings from these powders by Plasma Technology Incorporated and Caterpillar are gratefully acknowledged.

\section{OPEN ACCESS}

This article is distributed under the terms of the Creative Commons Attribution Noncommercial License which permits any noncommercial use, distribution, and reproduction in any medium, provided the original author(s) and source are credited.

\section{REFERENCES}

1. M. Telford: Mater. Today, 2004, vol. 3, pp. 36-43.

2. N. Sorensen, and R. Diegle: in Metals Handbook, vol. 13, Corrosion, 9th ed., J.R. Davis and J.D. Destefani, eds., ASME, New York, NY, 1987, pp. 864-70.

3. D. Polk and B. Giessen: in Overview of Principles and Applications, Metallic Glasses, J. Gilman and H. Leamy, eds., ASME, New York, NY, 1978, pp. 2-35.

4. K. Kishitake, H. Era, and F. Otsubo: J. Thermal Spray Technol., 1996, vol. 5 (2), pp. 145-53.

5. S. Pang, T. Zhang, K. Asami, and A. Inoue: Mater. Trans., 2002, vol. 43 (8), pp. 2137-42.

6. S. Pang, T. Zhang, K. Asami, and A. Inoue: Acta. Mater., 2002, vol. 50, pp. 489-97.

7. F. Guo, S. Poon, and G. Shiflet: Metallic Appl. Phys. Lett., 2003, vol. 83 (13), pp. 2575-77.

8. Z. Lu, C. Liu, and W. Porter: Metallic Appl. Phys. Lett., 2003, vol. 83 (13), pp. 2581-83.

9. V. Ponnambalam, S. Poon, and G. Shiflet: JMR, 2004, vol. 19 (5), p. 1320.

10. D. Chidambaram, C. Clayton, and M. Dorfman: Surface Coat. Technol., 2004, vol. 176, pp. 307-17.

11. J.C. Farmer, J.J. Haslam, S.D. Day, T. Lian, C.K. Saw, P.D. Hailey, J.-S. Choi, R.B. Rebak, N. Yang, J.H. Payer, J.H. Perepezko, K. Hildal, E.J. Lavernia, L. Ajdelsztajn, D.J. Branagan, and L.F. Aprigliano: J. Mater. Res., 2007, vol. 22 (8), pp. 2297-2311.

12. J. Farmer, J. Haslam, S. Day, T. Lian, C. Saw, P. Hailey, J. Choi, N. Yang, C. Blue, W. Peter, J. Payer, and D. Branagan: Symp. in Honor of Hugh Issacs, 210th ECS Meeting, N. Missert, ed.; ECS Trans., ECS, 2006, vol. 2 (31), pp. 485-96.

13. J. Farmer, J. Haslam, S. Day, T. Lian, C. Saw, P. Hailey, J.-S. Choi, R. Rebak, N. Yang, R. Bayles, L. Aprigliano, J. Payer, J. Perepezko, K. Hildal, E. Lavernia, L. Ajdelsztajn, D.J. Branagan, and M.B. Beardsely: Symp. $N N$, Materials Research Society Symposium Proceedings, Warrendale, PA, 2006, vol. 985, pp. 255-60.

14. J. Farmer, J. Haslam, S. Day, T. Lian, R. Rebak, N. Yang, and L. Aprigliano: PVP2006-ICPVT11-93835, ASME, New York, NY, 2006.

15. J. Farmer, J. Haslam, S. Day, D. Branagan, C. Blue, J. Rivard, L. Aprigliano, N. Yang, J. Perepezko, and M. Beardsley: PVP200571664, ASME, New York, NY, 2005.

16. D. Branagan: U.S. Patent Application No. 20040250929, filed Dec. 16, 2004

17. D. Branagan: U.S. Patent Application No. 20040253381, filed Dec. 16, 2004

18. T. Lian, D. Day, P. Hailey, J.-S. Choi, and J. Farmer: Symp. NN, Materials Research Society Symposium Proceedings, Warrendale, PA, 2006, vol. 985, pp. 275-80.

19. J.-S. Choi, C. Lee, J. Farmer, D. Day, M. Wall, C. Saw, M. Boussoufi, B. Liu, H. Egbert, D. Branagan, and A. D'Amato: Symp. NN, Materials Research Society Symposium Proceedings, Warrendale, PA, 2006, vol. 985, pp. 249-55.

20. C. Farmer, J.-S. Choi, C.K. Saw, R.H. Rebak, S.D. Day, T. Lian, P.D. Hailey, J.H. Payer, D.J. Branagan, and L.F. Aprigliano: J. Nucl. Technol., 2008, vol. 161 (2), pp. 169-89.

21. C.K. Saw: in X-Ray Scattering Techniques for Characterization Tools in the Life Sciences, Nanotechnologies for the Life Science, C. Kumar, ed., Wiley-VCH Verlag GmbH and Company, KGaA, Weinheim, 2006, pp. 354-78.

22. C.K. Saw and R.B. Schwarz: J. Less-Common Met., 1988, vol. 140, pp. 385-93.

23. J.E. Harrar, J.F. Carley, W.F. Isherwood, and E. Raber: Report of the Committee to Review the Use of J-13 Well Water in Nevada Nuclear Waste Storage Investigations, UCID-21867, LLNL, Livermore, CA, 1990.

24. G.E. Gdowski: YMP TIP-CM-06, Rev. CN TIP-CM-06-0-2, LLNL, Livermore, CA, 1997.

25. G.E. Gdowski: YMP TIP-CM-07, Rev. CN TIP-CM-07-0-2, LLNL, Livermore, CA, 1997.

26. G.E. Gdowski: YMP TIP-CM-08, Rev. CN TIP-CM-08-0-2, LLNL, Livermore, CA, 1997.

27. J. Farmer, S. Lu, D. McCright, G. Gdowski, F. Wang, T. Summers, P. Bedrossian, J. Horn, T. Lian, J. Estill, A. Lingenfelter, and W. Halsey: General and Localized Corrosion of High-Level Waste 
Container in Yucca Mountain, Transportation, Storage, and Disposal of Radioactive Materials, ASME, New York, NY, PVP, 2000, vol. 408, pp. 53-70.

28. Mineral Commodity Summaries, United States Geological Survey (USGS), January, 2005: Iron and Steel-M. Fenton; Cobalt-K.B. Shedd; Nickel-P.H. Kuck; Chromium-J.F. Papp; Molybdenum-M.J. Magyar and J.W. Blossom; Tungsten-K.B. Shedd; Manganese - T.S. Jones; Titanium -J. Gambogi.

29. J. Farmer, C. Earl, C. Doty, D. Spence, J. Walker, F. Wong, J. Payer, G.-Q. Lu, D.E. Clark, D.C. Folz, A. Heuer, O. Graeve, D. Branagan, C. Blue, J. Rivard, J. Perepezko, L. Kaufman, N. Yang, E. Lavernia, J. Haslam, E. Lemieux, L. Aprigliano, B. Beardsley, T. Weaver, B. Edwards, B. Brown, A. Halter, B Bayles, and J. Lewandowski: DARPA-DOE High Performance CorrosionResistant Materials (HCPRM) Principal Investigator's Meeting, Turtle Bay Resort, Oahu, HI, Jan. 10-13, 2005, UCRL-PRES214672, Lawrence Livermore National Laboratory, Livermore, CA, 2005.

30. J.C. Farmer: UCRL-PRES-219330, Energy and Environment Directorate Review Committee, Mar. 7-9, 2006, Lawrence Livermore National Laboratory, Livermore, CA, 2006.

31. J.C. Farmer: UCRL-SR-219257, Jan. 2006; contributions by J.C. Farmer, J.-S. Choi, J.J. Haslam, S.D. Day, N. Yang, T. Headley, G. Lucadamo, J.L Yio, J. Chames, A. Gardea, M. Clift, C.A. Blue, W.H. Peters, J.D.K. Rivard, D.C. Harper, D. Swank, R. Bayles and E.J. Lemieux, Robert Brown and Theresa M. Wolejsza, L.F. Aprigliano, D.J. Branagan, M.C. Marshall, Brian E. Meacham, E. Joseph Buffa, M. Brad Beardsley, E.J. Lavernia, J. Schoenung, L. Ajdelsztajn, J. Dannenberg, O.A. Graeve, J.J. Lewandowski, John H. Perepezko, Kjetil Hildal, L.P. Kaufman, and J. Boudreau, Lawrence Livermore National Laboratory, Livermore, CA, 2006.

32. J.C. Farmer, J.J. Haslam, and S.D. Day: UCRL-SR-218144, Jan. 2006, Lawrence Livermore National Laboratory, Livermore, CA, 2006.

33. J. Farmer, J. Haslam, S. Day, T. Lian, C. Saw, P. Hailey, J.-S. Choi, N. Yang, C. Blue, W. Peter, R. Bayles, R. Brown, J. Payer, J. Perepezko, K. Hildal, E. Lavernia, L. Ajdelsztajn, D.J. Branagan, J. Buffa, M. Beardsley, L. Aprigliano, and J. Boudreau: UCRL-TM-224159, Aug. 30, 2006, Lawrence Livermore National Laboratory, Livermore, CA, 2006.

34. J.-S. Choi, J. Farmer, and C. Lee: UCRL-MI-220385, Apr. 5, 2006, Lawrence Livermore National Laboratory, Livermore, CA, 2006; Proc. CALPHAD Meeting, Haifa, Israel, May 11, 2007, vol. 31, p. 408.

35. C.C. Scheffing, K. Jagannadham, M.-S. Yim, M.A. Bourham, J.C. Farmer, J.J. Haslam, S.D. Day, and D.V. Fix: Properties of
Titanium-Nitride for High-Level Waste Packaging Enhancement, Nuclear Technology, American Nuclear Society, La Grange Park, IL, 2006, vol. 156, pp. 213-21.

36. J. Farmer, J. Haslam, S. Day, T. Lian, C.-K. Saw, P. Hailey, J.-S. Choi, R. Rebak, J. Payer, C. Blue, W. Peters, and D. Branagan: Proc. Materials Science \& Technology 2007, Detroit, MI, Sept. 1620, 2007, American Ceramic Society (ACerS), Association for Iron \& Steel Technology (AIST), American Society of Metals (ASM), and The Minerals, Metals \& Materials Society (TMS), Warrendale, PA, 2007, pp. 381-92.

37. L.F. Aprigliano, S.D. Day, J.J. Haslam, J.C. Farmer, and R.B. Rebak: Proc. Materials Science \& Technology 2007, Sept. 16-20, 2007, Detroit, MI, American Ceramic Society (ACerS), Association for Iron \& Steel Technology (AIST), American Society of Metals (ASM) and The Minerals, Metals \& Materials Society (TMS), Warrendale, PA, 2007, pp. 393-400.

38. J.-S. Choi, J. Farmer, C. Lee, L. Fischer, M. Boussoufi, B. Liu, and H. Egbert: Proc. Materials Science \& Technology 2007 Conf. and Exhib., Sept. 16-20, 2007, Detroit, MI, American Ceramic Society (ACerS), Association for Iron \& Steel Technology (AIST), American Society of Metals (ASM) and the Minerals, Metals \& Materials Society (TMS), Warrendale, PA, 2007, pp. 431-42.

39. J. Farmer, S. Day, T. Lian, C.-K. Saw, P. Hailey, J. Payer, L. Aprigliano, B. Beardsley, and D. Branagan: Proc. Materials Science \& Technology 2007 Conf. and Exhib., Detroit, MI, Sept. 1620, 2007, American Ceramic Society (ACerS), Association for Iron \& Steel Technology (AIST), American Society of Metals (ASM) and The Minerals, Metals \& Materials Society (TMS), Warrendale, PA, 2007, pp. 469-80.

40. J. Farmer: Proc. Materials Science \& Technology 2007 Conf. and Exhib., Sept. 16-20 2007, Detroit, MI, American Ceramic Society (ACerS), Association for Iron \& Steel Technology (AIST), American Society of Metals (ASM), and The Minerals, Metals \& Materials Society (TMS), Warrendale, PA, 2007, pp. 535-66.

41. C.K. Saw, T. Lian, S.D. Day, and J.C. Farmer: Proc. Materials Science \& Technology 2007 Conf. and Exhib., Detroit, MI, Sept. 16-20, 2007, American Ceramic Society (ACerS), Association for Iron \& Steel Technology (AIST), American Society of Metals (ASM), and The Minerals, Metals \& Materials Society (TMS), Warrendale, PA, 2007, pp. 579-87.

42. R.B. Rebak, S.D. Day, T. Lian, P.D. Hailey, and J.C. Farmer: Metall. Mater. Trans. A, 2008, vol. 39A, pp. 225-34. doi:10.1007/ s11661-007-9460-7.

43. O.A. Graeve, R. Kanakala, L. Kaufman, K. Sinha, E. Wang, B. Pearson, and J.C. Farmer: Mater. Lett., 2007, DOI 10.1016/ j.matlet.2008.01.092/4 pages. 